\title{
Kształcenie zawodowe w rzemiośle osób z niepełnosprawnością
}

\begin{abstract}
The article is devoted to the analysis of the potential for counteracting the social exclusion of people with mild intellectual disability through educational and professional activation in craftsmanship. Within the scope of the subject, the author presents the potential of education in craft workshops in Poland and, comparatively, in craft professions in Germany. The article analyses the advantages of vocational training in craftsmanship for counteracting social exclusion, but also shows institutional barriers. The thesis of the article is that, given the large scale of vocational education in crafts in Poland, this type of learning does not fully realise the potential for the professional activation of people with mild intellectual disability. To confirm this, the article presents the activities aimed at introducing a solution concerning the possibility of obtaining qualifications by persons with mild intellectual disability who are learning some craft. These postulated qualifications are described by the Polish Craft Association as a journeyman's assistant.
\end{abstract}

Keywords: vocational education, people with disabilities, craft, employers, professions

\section{Wprowadzenie}

ształcenie zawodowe osób z niepełnosprawnością w rzemiośle otwiera znaczące możliwości z punktu widzenia wyrównywania szans edukacyjnych oraz zawodowych. Kwestia ta dotyczy młodzieży, która potencjalnie może zdobyć wykształcenie branżowe i następnie podjąć pracę m.in. w ramach mikro, małej 
i średniej przedsiębiorczości, obejmującej ponad sto zawodów klasyfikowanych w Polsce jako zawody rzemieślnicze ${ }^{1}$.

Dla zobrazowania najpopularniejszych pod względem podejmowania edukacji zawodów rzemieślniczych można wskazać takie jak: fryzjer, mechanik pojazdów samochodowych, kucharz, cukiernik, stolarz, elektryk, monter zabudowy i robót wykończeniowych w budownictwie, ślusarz, monter sieci instalacji i urządzeń sanitarnych. Wymienione zawody obejmują średnio ok. 75\% kształcenia i zarazem egzaminów czeladniczych wieńczących edukację w rzemiośle, co w skali kraju przekłada się na powyżej 20 tys. przeprowadzanych egzaminów w izbach rzemieślniczych rocznie ${ }^{2}$.

Celem artykułu jest analiza potencjału w zakresie przeciwdziałania wykluczeniu społecznemu osób z niepełnosprawnością intelektualną w stopniu lekkim poprzez aktywizację edukacyjno-zawodową w rzemiośle. W ramach tak sformułowanej tematyki zaprezentowany zostanie potencjał kształcenia w zakładach rzemieślniczych w Polsce oraz porównawczo tematyka kształcenia w zawodach rzemieślniczych w Niemczech. Analiza porównawcza kształcenia zawodowego w rzemiośle polskim i niemieckim ma na celu uogólnienie polskich doświadczeń w zakresie kształcenia rzemieślniczego. Tym samym stwarza to możliwość aplikacji dobrych praktyk w ramach systemów edukacyjnych w innych krajach. Istotne jest również wyeksponowanie w obydwu krajach potencjału tego segmentu gospodarki w zakresie przeciwdziałania wykluczeniu społecznemu.

W prezentowanym artykule analizie nie zostaną poddane wyłącznie atuty kształcenia zawodowego w rzemiośle na rzecz przeciwdziałania wykluczeniu społecznemu. Celem opracowania jest również analiza barier instytucjonalnych, które powodują, że przy dużej skali prowadzonej edukacji zawodowej w rzemiośle w Polsce, nie jest ona wykorzystywana stosownie do istniejącego potencjału aktywizacji zawodowej osób z niepełnosprawnością intelektualną w stopniu lekkim. Na potwierdzenie tego zaprezentowane zostanie studium przypadku dotyczące działań na rzecz wprowadzenia rozwiązania dotyczącego możliwości uzyskiwania kwalifikacji przez kształcące się w rzemiośle osoby z niepełnosprawnością intelektualną w stopniu lekkim. Te postulowane kwalifikacje określane są przez Związek Rzemiosła Polskiego mianem pomocnika czeladnika ${ }^{3}$.

1 Wielkopolska Izba Rzemieślnicza w Poznaniu, Alfabetyczny wykaz zawodów rzemieślniczych, http://www.irpoznan.com.pl/userfiles/files/oswiata\%202018/lista\%20zawod\%C3\%B3w\%20pdf.pdf [2.01.2020].

2 Opracowanie własne na podstawie: Informacja oświatowa Związku Rzemiosła Polskiego za lata 2009-2017, materiał powielony.

${ }^{3}$ Stanowisko Związku Rzemiosła Polskiego w sprawie zmian wynikających z projektu ustawy o zmianie ustawy - Prawo oświatowe i ustawy o systemie oświaty oraz niektórych innych ustaw (projekt przekazany do konsultacji w dniu 26 czerwca 2018 r.). 


\section{Osoby z niepełnosprawnością intelektualną w stopniu lekkim w systemie edukacji}

System edukacji w Polsce coraz bardziej otwiera się na potrzebę przygotowania osób z niepełnosprawnością do funkcjonowania na otwartym rynku pracy. Jest to zgodne z ideą podejścia humanistycznego, zgodnie z którym każdy człowiek powinien mieć szansę znalezienia „swojego miejsca w życiu”, bez względu na dysfunkcje i ograniczenia. Przykładem takiego ograniczenia jest niepełnosprawność intelektualna w stopniu lekkim, która przejawia się w funkcjonowaniu poznawczym, emocjonalnym i społecznym. Przy czym, jak podkreśla Ministerstwo Edukacji Narodowej w swoim stanowisku, niepełnosprawność intelektualna w stopniu lekkim nie jest warunkiem realizacji odrębnej podstawy programowej w ramach edukacji szkolnej, w tym w ramach edukacji zawodowej:

Uczniowie bez niepełnosprawności oraz uczniowie z niepełnosprawnościami, których rozwój intelektualny jest prawidłowy dla wieku lub kształtuje się na p ozi o mie niepełnosprawności intelektualnej w stopniu lekkim [wyróżnienie-K.B.], realizują tę samą podstawę programową wychowania przedszkolnego oraz podstawę programową kształcenia ogólnego określoną dla szkół danego typu oraz podstawę programową kształcenia w zawodach określoną w rozporządzeniach Ministra Edukacji Narodowej ${ }^{4}$.

W konsekwencji istnieje trudność w uchwyceniu statystycznym ścieżki edukacyjnej osób z niepełnosprawnością intelektualną w stopniu lekkim. Wynika to przede wszystkim z pewnego „rozmycia” tej kategorii w szkołach ogólnodostępnych i specjalnych. W konsekwencji wnioskowanie o sytuacji tych osób jest utrudnione na etapie edukacji szkolnej, a w momencie ukończenia szkoły - praktycznie niemożliwe. Osoby z niepełnosprawnością intelektualną w stopniu lekkim są często przez organy rządowe czy samorządowe traktowane jako pełnosprawne, a zatem jest to w takim ujęciu kategoria społeczna niewymagająca oddzielnych badań. W efekcie osoby te stają przed wyzwaniami związanymi z tym, iż nie są do nich dostosowane w szkołach branżowych treści programowe kształcenia ogólnego, jak też treści w zakresie teoretycznej nauki zawodu i związane z tym wymogi egzaminacyjne.

Przyczyną obniżonego funkcjonowania intelektualnego mogą być tzw. przyczyny społeczne, zaniedbania edukacyjne, wychowanie w środowisku ubogim w bodźce stymulujące poznawczo, i - jeśli osoby te podejmą edukację i działania rehabilitacyjne - wiele dysfunkcji może zostać zniwelowanych, a bariery rozwojowe zlikwidowane. Stwarza to szansę na równoprawne i pełne uczestnictwo w życiu społecznym dla osób z niepełnosprawnością intelektualną w stopniu lekkim.

\footnotetext{
${ }^{4}$ https://www.gov.pl/web/edukacja/podstawa-programowa6 [19.05.2019].
} 
A różnorodność może stanowić czynnik wzbogacający społeczeństwo, jeśli jego członkowie potrafią efektywnie komunikować się i współżyć w różnych układach społecznych. Możliwość wykorzystania tej szansy mogą i powinny wspierać nowe rozwiązania w szkolnictwie zawodowym, jak choćby przywoływane w dalszej części opracowania studium przypadku dotyczące postulatu wprowadzenia w ramach praktycznego kształcenia zawodowego oraz certyfikacji przed komisjami egzaminacyjnymi izb rzemieślniczych „pomocnika czeladnika”.

Efektywne rozwiązania w zakresie edukacji zawodowej, umożliwiającej podjęcie pracy zarobkowej, są kluczowe dla społecznego funkcjonowania osób z niepełnosprawnością. Aktywność zawodowa poza funkcją zarobkową odgrywa bowiem istotną rolę w wymiarze pozaekonomicznym, gdyż daje możliwość zaangażowania w życie społeczne, jak też podnosi samoocenę i zapewnia „wiarę we własne siły”. Należy przyjąć, że samoocenę w największym stopniu kształtują układy społeczne, takie jak: rodzina, otoczenie społeczne i zawodowe.

W literaturze przedmiotu powstało wiele definicji niepełnosprawności intelektualnej. Najłagodniejszą jej formą jest niepełnosprawność intelektualna w stopniu lekkim. Powszechnie przyjmuje się, że odpowiada ona funkcjonowaniu intelektualnemu 9-12-letniego dziecka i szacuje się, że ma ją ok. 85\% wszystkich osób z niepełnosprawnością intelektualną . W grę wchodzi tutaj głównie szeroko rozumiane obniżenie funkcji poznawczych. Osoba z niepełnosprawnością intelektualną w stopniu lekkim generalnie jest samodzielna i zaradna społecznie, a jej życie rodzinne zasadniczo nie napotyka na trudności, bowiem umiejętność komunikowania się z innymi ludźmi u takich osób generalnie kształtuje się na poziomie zdolności do nawiązywania i podtrzymywania rozmowy. Ponadto osoby z niepełnosprawnością intelektualną w stopniu lekkim w większości nabywają samodzielność w codziennym funkcjonowaniu oraz umiejętność wykonywania prostych czynności domowych ${ }^{6}$.

Omawiana kategoria osób może mieć problemy z rozpoznawaniem podobnych liter czy cyfr, jak też z zauważaniem związków między postrzeganymi treściami. Ogólnie spostrzegają one świat w sposób podobny do osób pełnosprawnych, jednak nieco uboższy. Należy przy tym zwrócić uwagę, że proces spostrzegania u osób z niepełnosprawnością intelektualną w stopniu lekkim jest zależny od wyćwiczenia i doświadczenia. Problematyczne może być dla nich również koncentrowanie uwagi (szczególnie na treściach abstrakcyjnych) czy ich dzielenie. W przypadku osób niepełnosprawnych intelektualnie w stopniu lekkim skomplikowana jest również kwestia pamięci. Zauważa się w tym przypadku dobrą pamięć mechaniczną i słabą logiczną i dowolną. Ciekawym zjawiskiem są przypadki występowania wybitnej pamięci mechanicznej - fotograficznej. Słabości w zapamiętywaniu treści przy-

${ }^{5}$ L. Cierpiałkowska, Psychopatologia, Scholar, Warszawa 2012, ss. 174-194.

${ }^{6}$ M.E.P. Seligman, E.F. Walker, D.L. Rosenhan, Psychopatologia, Zysk i S-ka, Poznań 2003, ss. 354-360. 
czynowo-skutkowych prowadzą z kolei do częstych zmyśleń mających na celu uzupełnianie luk w pamięci.

Tym, co najbardziej różni osoby z niepełnosprawnością intelektualną w stopniu lekkim od osób pełnosprawnych intelektualnie są ograniczenia w procesach myślowych. U tych pierwszych brak jest bowiem umiejętności myślenia abstrakcyjnego, przez co dominuje u nich myślenie konkretno-obrazowe, co powoduje, że myślenie osób z niepełnosprawnością intelektualną w stopniu lekkim odnosi się jedynie do konkretnej sytuacji, której w danym momencie doświadczają. Wiąże się z tym niezdolność samodzielnego myślenia oraz brak umiejętności tworzenia pojęć, co oznacza, że osoby takie nie potrafią wyodrębniać istotnych cech z przedmiotów i uogólniać tych cech, czyli łączyć cechy wspólne dla całej klasy danych przedmiotów ${ }^{9}$. W związku z niezdolnością do myślenia abstrakcyjnego, a co za tym idzie z niezdolnością do samodzielnego myślenia, osoby z niepełnosprawnością intelektualną w stopniu lekkim nie powinny wykonywać zadań zawodowych związanych z podejmowaniem decyzji. Tym bardziej, że osoby te słabo sobie radzą z wyciąganiem wniosków i rozumowaniem przyczynowo-skutkowym.

Osiągnięcie celów polityki włączającej jest szczególnie trudne ze względu na stereotypy, uprzedzenia oraz niską świadomość społeczną dotyczącą potencjału osób z niepełnosprawnością. Edukacja jest jedną z najistotniejszych i może być jedną z najbardziej skutecznych form rehabilitacji i aktywizacji osób z niepełnosprawnością intelektualną w stopniu lekkim. Odpowiednie warunki nauki oraz formy przekazywania wiedzy umożliwiają osobom z niepełnosprawnością intelektualną odnaleźć się w realiach życia społecznego. Wspólna nauka i praca osób pełnosprawnych i z niepełnosprawnością przyczynia się do integracji całego społeczeństwa. Stworzenie możliwości edukacji osób z niepełnosprawnością na równych prawach i warunkach z resztą społeczeństwa stanowi również właściwą drogę do wprowadzenia ich w realia życia zawodowego. Obecnie po ukończeniu edukacji osoby z niepełnosprawnością intelektualną w stopniu lekkim napotykają na znaczne problemy w odnalezieniu się na rynku pracy. Podjęcie pracy zarobkowej powinno stanowić naturalną konsekwencję zakończenia procesu edukacji.

Działania mające na celu wyrównywanie szans, integrację ze społeczeństwem osób z niepełnosprawnością oraz walkę z dyskryminacją są podejmowane przez państwa członkowskie Unii Europejskiej i podległe jej instytucje. Znaczna część tych przedsięwzięć dotyczy dwóch aspektów życia społecznego, które w największym stopniu wpływają na rozwój i życie jednostki. Te aspekty to edukacja i praca.

7 W. Otrębski, Osoby z upośledzeniem umysłowym w sytuacji pracy, Towarzystwo Naukowe KUL, Lublin 2001, ss. 27-28.

${ }^{8}$ Z. Sękowska, Dziecko upośledzone umysłowo, w: Z. Sękowska (red.), Wybrane zagadnienia z psychologii i pedagogiki upośledzonych, Wydawnictwo UMCS, Lublin 1976, ss. 16-18.

${ }^{9}$ M. Przetacznikowa, G. Makiełło-Jarża, Podstawy psychologii ogólnej, WSiP, Warszawa 1992, s. 115. 
Należy odnotować wielość zróżnicowanych działań zorientowanych na wsparcie osób niepełnosprawnych w skali nie tylko Polski, ale i szerzej, Unii Europejskiej. Różnorodność form i skali wsparcia w poszczególnych krajach, jak również, poza wszystkim, kryteriów orzekania o niepełnosprawności stanowi zasadniczą przeszkodę w standaryzacji orzecznictwa i prawodawstwa w skali całej Unii Europejskiej w najbliższej perspektywie czasowej. Pozostaje zatem dzielenie się doświadczeniami i dobrymi praktykami w wymiarze międzynarodowym odnośnie do aktywizacji osób z niepełnosprawnością poprzez system kształcenia zawodowego.

\section{Dualne kształcenie zawodowe w rzemiośle niemieckim}

Aby zostać rzemieślnikiem w Niemczech, konieczne jest posiadanie właściwych kwalifikacji, niezbędnych do uzyskania pozwolenia na wykonywanie zawodu w izbie rzemieślniczej ${ }^{10}$. W Niemczech, podobnie jak w Polsce, jest ponad 130 uznanych zawodów rzemieślniczych ${ }^{11}$. Kluczową cechą niemieckiego rzemiosła jest funkcjonowanie w formie samorządu gospodarczego. Wiąże się to z obligatoryjną przynależnością w ramach wykonywania określonych zawodów do terytorialnej izby rzemieślniczej. Przy czym izby rzemieślnicze jako podmioty prawa publicznego realizują zadania m.in. z zakresu kształcenia zawodowego, które w Polsce są prerogatywą jednostek samorządu terytorialnego. W Polsce odmiennie, samorząd gospodarczy - izby rzemieślnicze i gospodarcze mają charakter podmiotów prawa prywatnego, nie obowiązuje obligatoryjna przynależność w tych izbach podmiotów gospodarczych z określonych branż. Mimo to izby oraz cechy rzemieślnicze realizują w Polsce zadania z zakresu kształcenia zawodowego w formie organizacji tej formy edukacji. A w przypadku izb rzemieślniczych w Polsce mają one uprawnienia państwowe do przeprowadzania egzaminów i następnie wystawiania świadectw czeladniczych i mistrzowskich.

Nauczanie zawodowe w niemieckim rzemiośle charakteryzuje długa tradycja kształcenia, sięgająca średniowiecza. Rzemiosło jest silnie związane z dualnym systemem kształcenia, polegającym na przemiennie prowadzonej edukacji trybem szkolnym oraz w miejscu pracy. Ta tradycja ma dzisiaj duże znaczenie w kształtowaniu profesjonalnej tożsamości w rzemiośle. To dzięki niej rzemiosło jest jednym z filarów systemu dualnego i intensywnie oddziałuje na metody kształcenia ${ }^{12}$.

Edukacja w rzemiośle pozostaje jednym z największych elementów składowych kształcenia zawodowego w Niemczech. Niemalże co trzecia młoda osoba uczy

${ }^{10}$ https://www.hwk-ff.de/witamy/ [22.08.2018].

${ }^{11}$ Lista zawodów rzemieślniczych jest dostępna na stronach: https://handwerks-power.de/ handwerksberufe-2/ i https://handwerk.de/gewerbe [22.08.2018].

${ }_{12}$ M. Ebbinghaus, F.H. Esser, Berufliche Bildung im Handwerk. Entwicklungen und Herausforderungen im Kontext von Digitalisierung und demografischem Wandel, BIBB, Bonn 2017, s. 20. 
się w rzemiośle, a co szósta jest w nim zatrudniona. Udział uczniów w całkowitej liczbie zatrudnionych w rzemiośle wynosi w Niemczech ok. 9\% ${ }^{13}$. Jeśli chodzi o rynek pracy w tym sektorze, to istnieje prawie milion niemieckich przedsiębiorstw rzemieślniczych, które skupiają 5,4 mln zatrudnionych ${ }^{14}$. Niemieckim centrum rzemiosła jest kraj związkowy Nadrenia Północna-Westfalia, w którym aktywnych jest ok. 190 tys. przedsiębiorstw rzemieślniczych zatrudniających 1,1 mln osób. W 2017 r. 27,6\% wszystkich uczniów szkolnictwa zawodowego uczyło się w rzemiośle. W całych Niemczech zawodu w rzemiośle uczy się 365 tys. młodych mężczyzn i kobiet, z czego aż 22\% (81 100 osób) w Nadrenii Północnej-Westfalii.

W 2017 r. wśród mężczyzn najpopularniejszymi zawodami były: mechanik samochodowy, elektronik, mechanik instalacji sanitarnych, grzewczych i podobne. Wśród kobiet popularnością cieszyło się fryzjerstwo, sprzedaż w gastronomii oraz pracownik biurowy ${ }^{15}$. W 2016 r. w rzemiośle zostało zawartych łącznie 141,7 tys. umów na naukę zawodu w miejscu pracy. Tym samym 27,2\% wszystkich umów o kształcenie dotyczyło rzemiosła. Co więcej, szacuje się, że wśród obecnej siły roboczej ok. 70\% stanowią osoby „wewnętrznie” wykształcone w rzemiośle. Potencjał niemieckiego rzemiosła sprawia, że jest innowatorem w działalności usługowej, jak też produkcyjnej ${ }^{16}$. Rzemiosło stanowi zatem jeden z filarów niemieckiej gospodarki, pełniąc rolę „pracodawcy i nauczyciela zawodu”.

System dualny jest w dużej mierze uzależniony od koniunktury rynkowej. Przez potrzeby gospodarki określa się potrzeby odnośnie do specjalistów pożądanych na rynku pracy. W ten sposób też kreowane są nowe kierunki kształcenia ${ }^{17}$. Dzięki temu wskaźnik NEET (odsetek młodych ludzi z problemami związanymi z przejściem ze szkoły do pracy) w krajach niemieckojęzycznych, w których funkcjonuje dualny system kształcenia zawodowego, jest o połowę niższy niż w Polsce czy Francji, gdzie przedsiębiorstwa mają zdecydowanie ograniczony wpływ na funkcjonowanie szkolnictwa ${ }^{18}$. Jest to istotna korzyść wynikająca z wdrożenia tego modelu edukacji.

Kraje, w których wdrożono edukację dualną, wyróżniają się pozytywnie, jeśli chodzi o poziom bezrobocia oraz czas poszukiwania pracy przez młodych ludzi, w porównaniu do krajów UE nieposiadających takiego modelu kształcenia. Wśród państw, w których funkcjonuje system dualny, wskaźniki gospodarcze znajdują się na stabilnym, zadowalającym poziomie. Są to m.in. Austria, Dania, Holandia

${ }^{13}$ https://www.hwkno.de/artikel/was-ist-handwerk-76,3412,163.html [20.08.2018].

${ }^{14}$ https://www.zdh-statistik.de/application/index.php?mID=3\&cID=47 [17.08.2018].

${ }^{15}$ https://www.zdh.de/daten-fakten/kennzahlen-des-handwerks/ [17.08.2018].

${ }^{16}$ K. Mueller, J. Thomae, Bedeutung der qualifikationsgebundenen Zugangsberechtigung im Handwerk für die Funktionsfähigkeit des dualen Ausbildungssystems, Deutches Handwerkinstitut, Getynga 2015, s. 7.

${ }_{17}$ M. Mazik-Gorzelańczyk, Kształcenie zawodowe w Polsce w perspektywie zmian i potrzeb gospodarki, Fundacja Friedricha Eberta, Warszawa 2016, s. 26.

18 A. Łada, Rynek pracy wyzwaniem, Kształcenie zawodowe szansq, Fundacja Konrada Adenauera, Warszawa 2017, s. 11. 
i Szwajcaria ${ }^{19}$. Co więcej, jeśli chodzi o niemiecki rynek niemalże połowa młodych kobiet i mężczyzn, którzy zostali wykształceni w zawodach rzemieślniczych, pozostają w wyuczonym zawodzie. Zdecydowanie częściej decydują się pracować w swoim fachu niż osoby, które uzyskały inne wykształcenie zawodowe. Ponadto, ok. jedna trzecia czeladników dokształca się. W porównaniu do innych osób czynnych zawodowo, czeladnicy natrafiają na mniejsze trudności związane z znalezieniem miejsca pracy. Warto również zauważyć, że osoby z tytułem czeladniczym częściej wykorzystują uzyskane kwalifikacje w swoim miejscu pracy. Nabyte przez nich umiejętności częściej zostają wykorzystane w praktyce niż w przypadku innych osób czynnych zawodowo ${ }^{20}$.

Badania wykazują, że realizowanie nauki w zakresie kształcenia zawodowego bardzo pozytywnie wpływa na przejście z systemu edukacji na rynek pracy. Wydaje się mieć również pozytywny wpływ na dostosowanie pracowników do zmian technologicznych i strukturalnych w ekonomii. Nauka w miejscu pracy umożliwia podjęcie w naturalny sposób obowiązków zawodowych.

W przypadku kształcenia w rzemiośle należy także wskazać korzyści społeczne, które są dostrzegane nie tylko w Niemczech, ale również w innych krajach realizujących kształcenie dualne. Poprzez nie rozumie się efekt pokoleniowy (wpływ osób o dłuższym stażu zawodowym na rozwój umiejętności), związki edukacji ze zdrowiem oraz spójność społeczną (zmniejszenie rozwarstwienia społecznego, zmniejszenie przestępczości czy wzrost tolerancji). Do korzyści społecznych zalicza się również włączenie społeczne poprzez edukację kategorii społecznych zagrożonych marginalizację społeczną, jak osoby z niepełnosprawnością.

\section{Kształcenie zawodowe w zakładach rzemieślniczych w Polsce ${ }^{21}$}

Analizując kształcenia zawodowe prowadzone w zakładach rzemieślniczych w Polsce w kontekście potencjału aktywizacji społecznej i zawodowej osób z niepełnosprawnością intelektualną w stopniu lekkim, należy podkreślić co najmniej dwie okoliczności.

Po pierwsze, należy zwrócić uwagę na skalę tego kształcenia i rozkład terytorialny. Okazuje się, że pomimo spadku liczby osób kształcących się zawodowo w takiej formie, to „baza edukacyjna rzemiosła” jest dostępna na obszarze całego kraju, w tym w mniejszych miejscowościach, czyli wszędzie tam, gdzie funkcjonują lokalne zakłady rzemieślnicze.

${ }^{19}$ W.D. Greinert, S. Wolf, Die Berufschule - radikale Neuorientierung oder Abstieg zur Restschule?, Universitätsverlag der TU, Berlin 2013, s. 14.

${ }^{20}$ M. Ebbinghaus, F.H. Esser, Berufliche Bildung im Handwerk..., s. 19.

${ }^{21}$ Opracowanie własne na podstawie: Informacja oświatowa Związku Rzemiosła Polskiego za lata 2009-2017, materiał powielony. 
Po drugie, podkreślenia wymaga to, że kształcenie w rzemiośle ma charakter dualny, czyli prowadzone jest przemiennie w szkole oraz w miejscu pracy, co w połączeniu z ograniczoną skalą prowadzonej działalności produkcyjnej czy usługowej, w porównaniu do firm średnich i dużych, stwarza warunki do nawiązania relacji bezpośrednich mistrz-uczeń. Osoby niemające możliwości funkcjonowania w ramach dużej załogi odnajdują się zatem w małym zakładzie rzemieślniczym. Mistrzowie szkolący posiadają nie tylko formalne uprawnienia pedagogiczne jako mistrzowie szkolący, ale też mają zwykle znaczące doświadczenie w zakresie kierowania zespołem i relacji międzyludzkich. Historyczna rola mistrza rzemiosła może więc być określona mianem mentora.

Prezentując analizę kształcenia w polskim rzemiośle z uwzględnieniem wymiaru terytorialnego, można wskazać, że liczba pracowników młodocianych zatrudnionych w zakładach rzemieślniczych w celu przygotowania zawodowego w 2009 r. w całej Polsce wyniosła ponad 93 tys. osób. Osiem lat później, w 2017 r., liczba ta osiągnęła wartość nieco ponad 64 tys. osób. Zanotowano zatem spadek w skali ogólnopolskiej o 31 p.p. Z roku na rok spadek tej liczby był systematyczny - od 2 do 7 p.p. Biorąc pod uwagę poszczególne izby rzemieślnicze, największy spadek liczby uczniów w analizowanym okresie odnotowano dla Szczecina (spadek o 2/3), Krakowa (spadek o 60 p.p.) oraz Kielc (spadek o połowę). Z kolei największy wzrost dotyczył w tym czasie Rybnika (blisko 3-krotny) oraz Nowego Sącza (o ponad połowę). Zarówno w 2009 r., jak i 8 lat później najwięcej młodocianych pracowników przygotowywało się do zawodu pod auspicjami Wielkopolskiej Izby Rzemieślniczej i mimo 27 p.p. spadku wciąż liczba takich osób utrzymuje się tam powyżej 10 tys. w skali roku.

Biorąc pod uwagę przyporządkowanie terytorialne poszczególnych izb według województw, największą liczbę młodocianych pracowników szkoli się w Wielkopolsce - w 2009 r. było to blisko 18 tys. osób, zaś w 2017 r. blisko 13 tys. osób (spadek o 28 p.p.). Drugie miejsce należy do Śląska (2009 - ponad 12 tys. osób, 2017 - ponad 8400 osób). We wszystkich województwach zanotowano spadek liczby młodocianych pracowników. Największy trend spadkowy dotyczył województwa świętokrzyskiego (spadek o 49 p.p.), najmniejszy natomiast województwa zachodniopomorskiego (spadek o 13 p.p.).

Aby w lepszy sposób zobrazować potencjał i dominację poszczególnych regionów pod względem analizowanych wartości, warto posłużyć się współczynnikiem lokalizacji. Współczynnik lokalizacji (wskaźnik lokalizacji) wykorzystywany w geografii ekonomicznej regionów jest miarą koncentracji działalności na danym obszarze w odniesieniu do obszaru referencyjnego. Wskaźnik lokalizacji obliczany jest według wzoru:

$$
L Q=\left(E_{i b}^{t} / E_{b}^{t}\right) /\left(E_{i r}^{t} / E_{r}^{t}\right)
$$


gdzie:

$\mathrm{E}_{\mathrm{ib}} \quad-$ zmienna w sektorze i, w obszarze badanym b, w danym okresie $\mathrm{t}$

$\mathrm{E}_{\mathrm{b}} \quad$ - zmienna we wszystkich sektorach w badanym obszarze b, w danym okresie $\mathrm{t}$

$\mathrm{E}_{\text {ir }}$ - zmienna w sektorze i, w obszarze referencyjnym r, w danym okresie t

$\mathrm{E}_{\mathrm{r}}$ - zmienna we wszystkich sektorach $\mathrm{w}$ obszarze referencyjnym $\mathrm{r}$, w danym okresie t.

Uzyskany wynik jest możliwy do interpretacji w następujący sposób:

- wartość LQ>3 oznacza bardzo silną koncentrację,

- wartość LQ>2 oznacza silną koncentrację,

- wartość LQ>1 oznacza, że w obszarze badanym koncentracja jest wyższa niż średnio w obszarze referencyjnym,

- wartość LQ=1 oznacza, że rozkład analizowanej zmiennej w obszarze badanym przebiega bardzo podobnie względem rozkładu tej zmiennej w obszarze referencyjnym,

- wartość LQ<1 oznacza potencjalny niedobór.

W tym przypadku obszarem referencyjnym jest liczba ludności w województwach według danych GUS. Innymi słowy, liczbę młodocianych pracowników w każdym województwie odniesiono do ogólnej liczby mieszkańców tych jednostek terytorialnych w danej jednostce czasu.

Na podstawie obliczeń uzyskano poniższe wartości współczynnika lokalizacji dla lat 2009 i 2017. Najwyższą wartość dla obydwu lat odnotowano dla Wielkopolski - jest to nieco ponad 2, co oznacza silną koncentrację potencjału. Warto zauważyć, że pomimo spadku liczby uczniów, wartość współczynnika nawet wzrosła o 0,03 p.p. Na drugiej pozycji znalazło się województwo opolskie z wartością współczynnika rzędu 1,77 (wzrost o 0,25 w ciągu 8 lat), choć w liczbach bezwzględnych ten region zajmuje w 2017 r. zaledwie 8 pozycję wśród województw. Trzecia pozycja należy do województwa pomorskiego z wartością 1,55 zarówno w 2009, jak i w 2017 r. Najniższe wartości współczynnika, a tym samym niską koncentrację potencjału zanotowano dla województw: mazowieckiego $(0,55)$, zachodniopomorskiego $(0,48)$ i lubelskiego $(0,44)$. Największy spadek wartości współczynnika w okresie 8 lat zanotowano w województwa świętokrzyskim - z 0,95 do 0,71 p.p.

Wraz ze spadkiem liczby młodocianych pracowników w latach 2009-2017 malała także liczba zakładów rzemieślniczych, które szkoliły takie osoby. Mimo trendu spadkowego, dynamika zmian była mniejsza, bowiem w ciągu 8 lat liczba zakładów zmalała o 12 p.p. Warto również zauważyć, że w latach 2016-2017 liczba zakładów nieznacznie wzrosła, co zakończyło regularny rokroczny spadek liczby zakładów w latach 2009-2015. Reasumując, w 2009 r. uczniów szkoliło blisko 27 tys. zakładów rzemieślniczych, zaś w 2017 - 23,5 tys. zakładów. 
Biorąc pod uwagę poszczególne izby rzemieślnicze, największy spadek liczby zakładów w analizowanym okresie zanotowano w Krakowie (spadek o 60 p.p.), Szczecinie (spadek o 59 p.p.) i w Mazowieckiej Izbie Rzemieślniczej (spadek o 52 p.p.). Natomiast w pięciu izbach odnotowano wzrost liczby zakładów szkolących uczniów, z czego największym wzrostem pochwalić się mogły Rybnik (ponad sześć razy więcej zakładów przez 8 lat) oraz Nowy Sącz (wzrost o 82 p.p.). Zarówno w 2009, jak i w 2017 r. największa liczba zakładów przygotowująca uczniów do zawodu zrzeszona była w Wielkopolskiej Izbie Rzemieślniczej (ponad 4 tys. podmiotów), które stanowiły 20\% wszystkich tego typu zakładów w Polsce. Drugie w kolejności Katowice to już jedynie nieco ponad 1,5 tys. zakładów.

W podziale według województw również Wielkopolska i Śląsk przodowały, jeśli chodzi o liczbę zakładów szkolących uczniów. Łącznie w tych dwóch regionach w 2017 r. znajdowało się blisko 40\% wszystkich tego typu podmiotów w kraju. W Wielkopolsce było to 5750 zakładów, co oznaczało, że w tym regionie znajdował się co czwarty zakład szkolący (wzrost o 8 p.p. w stosunku do 2009 r., najlepszy wynik wśród wszystkich województw), a na Śląsku 3376 zakładów (spadek o 13 p.p. od 2009 r.). Największy spadek, bo o ponad 1/3 w 8 lat, zanotowano w województwie świętokrzyskim (z 735 do 484 zakładów). Poza Wielkopolską jedynie jeszcze w dwóch województwach zanotowano nieznaczny wzrost ogólnej liczby zakładów szkolących uczniów: w opolskim i podkarpackim.

Posługując się ponownie współczynnikiem lokalizacji pozwalającym na lepsze zobrazowanie potencjału regionalnego w przypadku zakładów szkolących, można zauważyć, że znów Wielkopolska przodowała w rankingu województw z wartością współczynnika powyżej wartości „2” - zarówno w 2009, jak i w 2017 r., co oznacza silną koncentrację potencjału. Drugie miejsce, również podobnie, jak w przypadku liczby uczniów przysposabiających się do zawodu, zajmuje województwo opolskie z wartością współczynnika rzędu 1,85. W czołówce znalazły się także województwa: pomorskie, śląskie oraz kujawsko-pomorskie (w każdym przypadku wartość współczynnika powyżej „1”). Ostatnie trzy miejsca rankingu z najniższymi wartościami współczynnika zajmują te same województwa, co w przypadku rankingu potencjału związanego z liczbą młodocianych pracowników: mazowieckie, lubelskie i zachodniopomorskie.

Łączna liczba egzaminów zawodowych (mistrzowskich i czeladniczych) przeprowadzona w 2017 r. w izbach rzemieślniczych wyniosła blisko 32 tys. W 2009 roku było to łącznie ponad 34 tysiące egzaminów. W ciągu 8 lat zanotowano zatem spadek liczby przeprowadzanych egzaminów o 7 p.p. W przypadku egzaminów mistrzowskich, stanowiły one od $8 \%$ do $11 \%$ wszystkich przeprowadzanych egzaminów w analizowanym okresie. W ciągu 8 lat ich liczba spadła o 17 p.p. - z 3 tys. do nieco ponad 2,5 tys. W przypadku egzaminów czeladniczych stanowiących zdecydowaną większość wszystkich egzaminów (89\%-92\%) zanotowano spadek o 6 p.p. w latach 2009-2017 - z ponad 31 tys. do nieco ponad 29 tys. 
Zarówno w 2009, jak i w 2017 r. zdecydowanym liderem wśród izb przeprowadzających największą liczbę egzaminów czeladniczych był Poznań (odpowiednio 4259 i 3795 egzaminów), z kolei największa liczba egzaminów mistrzowskich przeprowadzana była w Katowicach: w 2009 r. było to 380 egzaminów, w 2017 - 338.

Dominacja wspomnianych dwóch izb przekłada się na rezultaty osiągnięte przez poszczególne województwa. Egzaminy czeladnicze w największej liczbie przeprowadzane były w Wielkopolsce. W 2017 r. było to ponad 5 tys. egzaminów, co stanowiło 17\% wszystkich egzaminów tego typu w kraju. Drugie miejsce należało do Śląska z liczbą ponad 3,4 tys. egzaminów czeladniczych, zaś trzecie miejsce należało do Lubelszczyzny, z liczbą prawie 3 tys. takich egzaminów. Tylko w czterech województwach liczba egzaminów czeladniczych w okresie 8 lat wzrosła - w województwo lubelskim w tym czasie podwojona została liczba takich egzaminów (z 1523 do 2957). Natomiast największy spadek liczby przeprowadzanych egzaminów czeladniczych zanotowano w województwie świętokrzyskim i był to spadek o połowę - z 1096 do 551 egzaminów.

Egzaminy mistrzowskie to dominacja województwa śląskiego (w 2017 r. 438 egzaminów - 17\% wszystkich tego typu w Polsce). Drugie miejsce należało do Wielkopolski z liczbą 294 egzaminów mistrzowskich. Powyżej 200 egzaminów tego typu w 2017 r. przeprowadzono jeszcze w województwach: mazowieckim, małopolskim i lubelskim. Trzy regiony zanotowały wzrost liczby przeprowadzanych egzaminów mistrzowskich w latach 2009-2017, w województwo lubuskim był on najbardziej wyraźny, bo wyniósł 50\% (z 66 do 99 egzaminów). Podobnie jak w przypadku egzaminów czeladniczych, również w przypadku egzaminów mistrzowskich to w województwie świętokrzyskim odnotowano największy spadek procentowy i również wyniósł on ok. 50 p.p. (spadek z 195 do 91 egzaminów).

Największą koncentrację potencjału związaną z liczbą przeprowadzanych egzaminów czeladniczych zanotowano w Wielkopolsce (wartość współczynnika koncentracji wyniosła w 2017 r. 1,9). Tuż za Wielkopolską znalazło się województwo lubelskie ze współczynnikiem 1,83 i wzrostem tej wartości niemal o „1” w okresie 8 lat, co jest związane ze znacznym wzrostem liczby przeprowadzanych egzaminów czeladniczych w tym regionie. Słabą koncentrację potencjału zanotowano dla województw: świętokrzyskiego $(0,58)$, łódzkiego $(0,53)$ i mazowieckiego $(0,51)$.

W przypadku egzaminów mistrzowskich na czele znajduje się województwo lubelskie (wartość współczynnika wyniosła w 2017 r. w tym regionie 1,7), dalej województwo lubuskie $(1,46)$ i śląskie $(1,45)$. Zdecydowanie najniższą koncentrację potencjału notowano dla województwa warmińsko-mazurskie, gdzie wartość współczynnika koncentracji wynosiła ok. 0,4.

W podsumowaniu analizy kształcenia w zakładach rzemieślniczych w Polsce istotne jest wskazania na to, że pomimo trendów spadkowych, jest to ciągle znacząca skala prowadzonej edukacji zawodowej. Zarazem istotna jest dbałość o promowanie uzyskiwania uprawnień mistrzowskich, które są podstawą kształcenia kadr w rzemiośle. 


\section{Podsumowanie - pomocnik czeladnika}

Postulat utworzenia „pomocnika czeladnika” jako najniższego stopnia kwalifikacji zawodowych w rzemiośle pojawił się jako próba wyjścia naprzeciw potrzebom osób z niepełnosprawnością intelektualną w stopniu lekkim. Wciąż pozostaje w sferze projektów, pomimo iż został sformułowany w latach 90. XX wieku przez Związek Rzemiosła Polskiego. W stanowisku Związku Rzemiosła Polskiego, jakie zajął on w 2018 r. w sprawie projektowanych zmian w prawie oświatowym, wskazano na potrzebę wprowadzenia egzaminu sprawdzającego w ramach egzaminu czeladniczego, którego zadanie wiązałoby się z wydaniem zaświadczenia, spełniającego wymogi określone dla wniosków składanych przez pracodawców ubiegających się o dofinansowanie części kosztów kształcenia. Postulat ten opierał się na założeniu, że w ten sposób rozwijałoby się kolejną ścieżkę możliwości uzyskiwania kwalifikacji przez kształcące się w rzemiośle osoby z niepełnosprawnością intelektualną w stopniu lekkim, a w konsekwencji zwiększałoby to ich możliwości zatrudnienia ${ }^{22}$.

Tymczasem problem powraca rokrocznie, gdy rozpoczyna się sesja egzaminacyjna. Wtedy uwidacznia się bariera, której niektórzy kandydaci na czeladników nie mogą przejść: „,uczący ich rzemieślnicy potwierdzają, że część praktyczną opanowali znakomicie. Są świetni manualnie, chętni do pracy, ale zupełnie nie radzą sobie z teorią, która jest bezwzględnie wymagana do zdobycia tytułu czeladnika” - twierdzi Karol Pufal, przewodniczący Wojewódzkiej Rady Zatrudnienia w Poznaniu (wiceprezes Wielkopolskiej Izby Rzemieślniczej)23.

Problemy pracodawców - rzemieślników, którzy dostrzegają potrzeby osób z niepełnosprawnością, mają długą historię, są niezmiennie sygnalizowane od kilkudziesięciu wręcz lat: „Przy obecnych rozwiązaniach prawnych pracodawca - mistrz szkolący, który bierze na siebie trud wykształcenia takiej osoby, z góry skazany jest na porażkę. Wiadomo, że nie skorzysta z premii finansowej należnej za wykształcenie ucznia, a co gorsza, będzie musiał w przygotowanie takiego kandydata włożyć o wiele więcej pracy, serca i cierpliwości. Trudno się dziwić, że mało kto chce się podejmować tak niewdzięcznego zadania. Tymczasem indywidualny i niekiedy dłuższy tok nauki powoduje, że takie osoby mogłyby z powodzeniem zdobyć kwalifikacje zawodowe i swoje miejsce na rynku pracy. Pracują z konkretnym pracodawcą, na konkretnym stanowisku i zdobywają ściśle określone umiejętności. [...] Bywa, że są w stanie funkcjonować tylko w tej jednej, wcześniej poznanej

${ }^{22}$ Stanowisko Zwiqzku Rzemiosła Polskiego w sprawie zmian wynikających z projektu ustawy o zmianie ustawy - Prawo oświatowe i ustawy o systemie oświaty oraz niektórych innych ustaw (projekt przekazany do konsultacji w dniu 26 czerwca 2018 r.).

${ }^{23}$ M. Rutkowska-Kalisz, Na co komu pomocnik czeladnika?, „Wielkopolski Rzemieślnik” 8/2011. 
firmie. Nigdzie indziej nie były w stanie znaleźć zatrudnienia” - zauważa Tomasz Wika, dyrektor Wielkopolskiej Izby Rzemieślniczej w Poznaniu²4.

Tytuł zawodowy „pomocnik czeladnika” oznaczałby dla pracodawcy, że nie może od niego wymagać pełni wiedzy i umiejętności, a zarazem zapewniałby potwierdzenie kwalifikacji. To konkretne rozwiązanie w zakresie systemu egzaminów zawodowych dałoby możliwość zdecydowanie lepszego, niż ma to obecnie miejsce, potencjału rzemiosła w Polsce w zakresie aktywizacji edukacyjno-zawodowej. Zarazem istotna jest konstatacja w ramach zaprezentowanej analizy edukacji zawodowej w rzemiośle, iż dla osób z niepełnosprawności intelektualną w stopniu lekkim jest to „przyjazne” środowisko nauki i pracy. Wiążę się to m.in. z bezpośrednimi, osobistymi relacjami w zakładach rzemieślniczych. Istotnym argumentem na rzecz dostępności miejsc edukacji i pracy w rzemiośle jest też zaprezentowany w artykule rozkład przestrzenny w skali kraju działalności edukacyjnej tego sektora gospodarczego.

\section{Literatura}

Cierpiałkowska L., Psychopatologia, Scholar, Warszawa 2012.

Ebbinghaus M., Esser F.H., Berufliche Bildung im Handwerk. Entwicklungen und Herausforderungen im Kontext von Digitalisierung und demografischem Wandel, BIBB, Bonn 2017.

Greinert W.D., Wolf S., Die Berufschule - radikale Neuorientierung oder Abstieg zur Restschule?, Universitätsverlag der TU, Berlin 2013.

Informacja oświatowa Związku Rzemiosła Polskiego za lata 2009-2017, materiał powielony.

Łada A., Rynek pracy wyzwaniem, Kształcenie zawodowe szansa, Fundacja Konrada Adenauera, Warszawa 2017.

Mazik-Gorzelańczyk M., Kształcenie zawodowe w Polsce w perspektywie zmian i potrzeb gospodarki, Fundacja Friedricha Eberta, Warszawa 2016.

Mueller K., Thomae J., Bedeutung der qualifikationsgebundenen Zugangsberechtigung im Handwerk für die Funktionsfähigkeit des dualen Ausbildungssystems, Deutches Handwerkinstitut, Getynga 2015.

Otrębski W., Osoby z upośledzeniem umysłowym w sytuacji pracy, Towarzystwo Naukowe KUL, Lublin 2001.

Przetacznikowa M., Makiełło-Jarża G., Podstawy psychologii ogólnej, WSiP, Warszawa 1992.

Rutkowska-Kalisz M., Na co komu pomocnik czeladnika?, „Wielkopolski Rzemieślnik” 8/2011.

Seligman M.E.P., Walker E.F., Rosenhan D.L., Psychopatologia, Zysk i S-ka, Poznań 2003.

Sękowska Z., Dziecko upośledzone umysłowo, w: Z. Sękowska (red.), Wybrane zagadnienia z psychologii i pedagogiki upośledzonych, Wydawnictwo UMCS, Lublin 1976.

24 Ibidem. 
Stanowisko Zwiq̨zku Rzemiosła Polskiego w sprawie zmian wynikajq̨cych z projektu ustawy o zmianie ustawy - Prawo oświatowe i ustawy o systemie oświaty oraz niektórych innych ustaw (projekt przekazany do konsultacji w dniu 26 czerwca 2018 r.).

Wielkopolska Izba Rzemieślnicza w Poznaniu, Alfabetyczny wykaz zawodów rzemieślniczych, http://www.irpoznan.com.pl/userfiles/files/oswiata\%202018/lista\%20zawod\%C3\%B3w\%20pdf.pdf [2.01.2020].

\section{Strony internetowe}

https://handwerk.de/gewerbe [22.08.2018].

https://handwerks-power.de/handwerksberufe-2/ [22.08.2018].

https://www.gov.pl/web/edukacja/podstawa-programowa6 [19.05.2019].

https://www.hwk-ff.de/witamy/ [22.08.2018].

https://www.hwkno.de/artikel/was-ist-handwerk-76,3412,163.html [20.08.2018].

https://www.zdh.de/daten-fakten/kennzahlen-des-handwerks/ [17.08.2018].

https://www.zdh-statistik.de/application/index.php?mID=3\&cID=47 [17.08.2018]. 
